World Lumen Congress 2021 | May 26-30, 2021 | Iasi, Romania

\title{
The Traumatic Life Experiences and Ontological Well-Being: Insights from Narrative Psychology and Self-Memory Theory
}

\author{
Seçil BÜLBÜL \& Serin İȘ̇̇ÇIK
}

https://doi.org/10.18662/wlc2021/11

How to cite: Bülbül, S., \& İşiaçık, S. (2021). The Traumatic Life Experiences and Ontological Well-Being: Insights from Narrative Psychology and Self-Memory Theory. In A. Sandu (vol. ed.), Lumen Proceedings: Vol. 17 World Lumen Congress 2021 (pp. 87-92). Iasi, Romania: LUMEN Publishing House. https://doi.org/10.18662/wlc2021/11 


\title{
The Traumatic Life Experiences and Ontological Well-Being: Insights from Narrative Psychology and Self-Memory Theory
}

\author{
Seçil BÜLBÜL ${ }^{1}$, Serin İȘİAÇIK²
}

Abstract

Ontological well-being adopts a holistic perspective on well-being like the narrative psychology when analysing life histories by referring to past, present, and future aspects of one's life. Relatedly, the self-memory view proposes that life events are self-evaluated. Based on the narrative psychology and self-memory approach, affective life events have a role in structuring self-perceptions and well-being. Therefore, turbulent external conditions such as the pandemic, uncertain environments and socioeconomic challenges may lead to unpleasant experiences for individuals. This study aims to examine the relationship between the perceived effects of traumatic life experiences and ontological well-being within the period of COVID 19 pandemic. It is intended to reveal the impact of traumatic experiences on ontological well-being of individuals in work life. A cross-sectional study was utilized throughout an online survey with the participation of 270 employees working in various private organizations. Following the statistical analyses, the findings were evaluated and both conceptual and practical discussions were provided.

Keywords: Ontological well- being, Post-traumatic stress disorder, Well-being, Traumatic life experiences, Narrative psychology, Self-memory theory.

\section{Introduction}

The turbulent external conditions (i.e., the pandemic outbreak and related socio-economic challenges) can damage the wellness of individuals, and employees may encounter many critical incidents during work. Being exposed to traumatic events and experiencing post-traumatic stress is expected to influence mental health, well-being, and organizational behaviors. While post-traumatic stress disorder (PTSD) is a clinical term and classified as a mental disorder that needs the attention of mental health professionals, a non-clinical assessment of PTSD is crucial to unveil the

\footnotetext{
${ }^{1}$ Assoc. Prof, Dr. Marmara University, Istanbul, Turkey, seciltastan@marmara.edu.tr

${ }^{2}$ Res. Asst., FMV Işı University, Istanbul, Turkey, serin.isiacik@isikun.edu.tr
} 
attitudes and behaviors in several social contexts (i.e., organizations). As such, the current study aims to understand the effect of the emotional, attitudinal, and behavioral symptoms that are related to post-traumatic stress disorder and the ontological well-being of individuals (Açıkgöz Karaoğlu, 2016).

\section{Conceptual Framework: Post-Traumatic Stress Disorder and Ontological Well-Being}

Although previous evidence showed that overall life satisfaction of individuals with PTSD is relatively low (Keim, Malesky, \& Strauser, 2003), there is a gap in research on post-trauma experiences in social contexts and their effect on well-being. Particularly, within the scope of positive psychology, well-being, resilience, life satisfaction, and happiness have been studied (American Psychiatriv Association, 2013; Diener, 2009; Lemay \& Ghazal, 2001; Seligman, et al., 2005; Zika \& Chamberlain, 1992). Recent research on well-being has proposed the concept of ontological well-being rather than the hedonic or eudaimonic approaches of well-being. Ontological well-being refers to a holistic approach by defining the subjective cognitive and emotional evaluation of one's life in a whole-time perspective. In other words, it is defined by individuals' assessment of their life as a project by considering their lives in the past, present, and future (Şimşek \& Kocayoruk, 2013). Parallel with the narrative psychology and selfmemory approaches, ontological well-being suggests that humans as the authors of their lives have their personal stories that can only be evaluated by themselves (Brown, 2006; Conway \& Pleydell-Pearce, 2000; Şimşek, 2009). Previous evidence showed the relationship between ontological wellbeing and several psychological factors as emotional intelligence, depression, five-factor model of personality, attachment, perceived parenting style, the purpose of life, emotional well-being, and early maladaptive schemas (Acıkgoz \& Karaoglu, 2016; Kuzu-Tasc1 2014; Şimşek \& Kocayoruk 2013; Yaman- Karahan 2016). Based on the theory and previous findings, PTSDrelated symptoms can be expected to predict the perceived ontological wellbeing of individuals. Hence, the hypothesis of the current research is as follows (Friedman, 2013).

Hypothesis: Perceived post-traumatic disorder symptoms negatively influence the perceived ontological well-being of individuals. 


\section{Methodology}

An online survey was conducted with a convenience sampling method. The sample consists of 270 (89 males, 181 females) participants. The mean educational level completed $(1=$ Primary school, $2=$ High school, $3=$ Bachelor's degree, $4=$ Master's degree, $5=\mathrm{PhD})$ was $3.11(S D=0.93)$. Most of the participants were single individuals (58.1\%). $63.7 \%$ of the sample stated having a challenging and/or traumatic life experience in the past and 23.3.\% of the participants have witnessed a closed one's traumatic experience. The frequency of experiencing traumatic events was mostly remarked as 'more than once' $(M=1.90, S D=.42) .40 .7 \%$ of individuals stated that natural disasters, accidents, unintentional human mistakes, uncontrollable environmental health/politics, etc. are the causes of their traumatic experience.

The DSM-IV-based "Post-traumatic Stress Disorder ChecklistCivilian" (PCL-C) with 17 items was used to address the symptoms after the traumatic experiences. The items have five levels indicating how much the respondent has been troubled by the symptoms (re-experiencing, avoidance, and hyperarousal) in the recent days, most frequently during the past few months. Hence, the participants rated their experiences as 0 (never) to 5 (always). Since this study does not have a clinical diagnosis purpose and the checklist was considered as suitable for the scope of the study, a scale based on DSM-IV classification was used (Keirn, et al., 2003).

"The ontological well-being" scale, developed by Şimsek and Kocayörük (2013), consists of a total of 24 items assessing the individuals' self-assessment for their past, present, and future. The scale has four subdimensions: "nothingness", "activation", "regret", and "hope". The internal reliability of the scale was .91 (Şimşek \& Kocayörük, 2013) and .75 in the present study. The ratings are based on a five-point scale for each question by evaluating through; "I don't feel at all" (1) to "I feel very intensely" (5).

\section{Findings}

Exploratory Factor Analysis (EFA) was performed to assess the factorial structure. The factors were named as "present activation", "past regret", "future hope", and "present nothingness", and they were included in the later analyses for a detailed understanding. Correlation analysis (Table 1) and simple regression analysis were performed to evaluate the relationships between the variables. There was a significant moderate relationship between PTSD and past regret; the negative and low relationship between 
PTSD and future hope; the positive and moderate relationship between PTSD and present nothingness $(p<.01)$. The descriptive results showed that symptoms of PTSD $(M=3,68, S D=1.06)$ was relatively high among the participants, and the magnitude of present nothingness $(M=2.85, S D=1.11)$ was higher than the other factors of ontological well-being.

Table 1. Means, standard deviations, and correlations

\begin{tabular}{llllllll}
\hline Variables & $\boldsymbol{M}$ & $\boldsymbol{S D}$ & $\mathbf{1}$ & $\mathbf{2}$ & $\mathbf{3}$ & $\mathbf{4}$ & $\mathbf{5}$ \\
\hline 1. PTSD & 3.67 & 1.06 & $-.334^{* *}$ & $.630^{* *}$ & $-.198^{* *}$ & $.558^{* *}$ \\
2.Present & 2.48 & 1.00 & & $-.321^{* *}$ & $.540^{* *}$ & $-.442^{* *}$ \\
activation & & & & & & \\
3.Past regret & 2.02 & 0.87 & & & $-.273^{* *}$ & $.629^{* *}$ \\
$\begin{array}{l}\text { 4.Future hope } \\
\text { 5.Present }\end{array}$ & 1.89 & 1.06 & & & & $-.357^{* *}$ \\
nothingness & 2.85 & 1.11 & & & & \\
\hline$* * p<.01$ & & & & & &
\end{tabular}

Table 2. Results of Simple Regression Analyses

\begin{tabular}{llll}
\hline Independent variable: PTSD & Beta & $\boldsymbol{t}$ value & $p$ value \\
\hline Present activation & -.334 & 5.807 & 0.01 \\
$R=.334 ; R^{2}=.112 ; F$ Value $=33.719$ & & \\
\hline $\begin{array}{l}\text { Past regret } \\
R=.630 ; R^{2}=.397 ; F \text { Value }=176,460\end{array}$ & 13,264 & 0.00 \\
\hline Present nothingness $\quad .558$ & 11.006 & 0.00 \\
$R=.558 ; R^{2}=.311 ; F$ Value $=121,128$ & & \\
\hline Future hope & -.198 & 3.301 & 0.001 \\
$R=.198 ; R^{2}=.039 ; F$ Value $=10.896$ & & \\
\hline
\end{tabular}

Regression analysis also showed that perceived PTSD symptoms significantly predict each of the components of ontological well-being. (Table 2). Hence, the main hypothesis of the study was supported. PTSD explained $11 \%$ percent of the change in present time activation, $40 \%$ of the change in past time regret, $\% 0.5$ of the change in future hope, $31 \%$ of the change in present time nothingness perception.

\section{Discussion and Future Suggestions}

Individuals' experiences of stressful events and traumatic incidents are important for organizational psychology (Tehrani, 2017). Perceived 
PTSD symptoms contributed to individuals' ontological well-being in the current research. These results may provide implications for today's work life-mental health (World Health Organisation, 2010) and ontological wellbeing of employees, and positive organizational behavior interventions can be implemented to increase ontological well-being. Based on current findings and previous evidence (Mohr, et al., 2021), this study suggests that the positive psychology approach in organizations not only increases positive behaviors but can also reduce negative emotions, behaviors, and attitudes. Nonetheless, future research should have more sample size to enable better generalizability of the findings. In addition, demographic characteristics may be included in the following research models as moderating variables.

\section{References}

Açıgöz Karaoğlu, B. (2016). Travma sonrası stres bozukluğu ve depresyon arasindaki iliskide ontolojik iyi-olusun arachle etkisi: bir yapısal essitlik modellemesi callsmast [The mediating effect of ontological well-being in the relationship between post-traumatic stress disorder and depression: a structural equation modeling study]. ([Unpublished doctoral dissertation]. İstanbul Arel Üniversity.

American Psychiatric Association. (2013). Anxiety disorders. DSM Library. https://doi.org/10.1176/appi.books.9780890425596.dsm05

Brown, A. D. (2006). A narrative approach to collective identities. Journal of Management Studies, 43(4), 731-753. https://doi.org/10.1111/j.14676486.2006.00609.x

Conway, M. A., \& Pleydell-Pearce, C. W. (2000). The construction of autobiographical memories in the self-memory system. Psychological Review, 107(2). https://doi.org/10.1037/0033-295x.107.2.261

Diener, E. (2009). Subjective Well-Being. In E. Diener (ed.), The Science of WellBeing. Springer.

Friedman, M. J. (2013). Finalizing PTSD in DSM5: Getting here from there and where to go next. Journal of Traumatic Stress, 26(5), 548-556. https://doi.org/10.1002/jts.21840

Keirn, J., Malesky Jr, L. A., \& Strauser, D. R. (2003). Post-traumatic stress disorder (PTSD), life satisfaction and work personality: exploring the relationship with disability. Journal of Applied Rehabilitation Counseling, 34(3), 41-45. https://doi.org/10.1891/0047-2220.34.3.41

Kuzu-Taşç1, D. (2014). Erken dönem uyumsuz, semalar ile depresyon ilişkisinin açlelanmasinda ontolojik iyi olus değģskeninin arac rolü: bir yol analiz̧ çalıs̆ması [Mediator role of ontological well-being variable in explaining the 
relationship between early maladaptive schemas and depression: a pathway analysis study]. [Unpublished thesis paper]. İstanbul Arel Üniversitesi.

Lemay, R., \& Ghazal, H. (2001). Resilience and positive psychology: Finding hope. Child \& Family, 5(1), 10-21.

https://www.semanticscholar.org/paper/Resilience-and-positivepsychology- $\% 3 \mathrm{~A}$-Finding-hope.-LemayGhazal/741e8b4d6ee79655372523d29f8eb6574ef5d31a

Mohr, C. D., Hammer, L. B., Brady, J. M., Perry, M. L., \& Bodner, T. (2021). Can supervisor support improve daily employee well being? Evidence of supervisor training effectiveness in a study of veteran employee emotions. Journal of Occupational and Organizational Psychology, 94(2), 400-426. https://doi.org/10.1111/joop.12342

Seligman, M. E., Steen, T. A., Park, N., \& Peterson, C. (2005). Positive psychology progress: empirical validation of interventions. American Psychologist, 60(5), 410. https://doi.org/10.1037/0003-066X.60.5.410

Şimşek, Ö. F. (2009). Happiness revisited: Ontological well-being as a theory-based construct of subjective well-being. Journal of Happiness Studies, 10(5), 505522. https://doi.org/10.1007/s10902-008-9105-6

Şimşek, Ö. F., \& Kocayörük, E. (2013). Affective reactions to one's whole life: Preliminary development and validation of the ontological well-being scale. Journal of Happiness Studies, 14(1), 309-343. https://doi.org/10.1007/s10902$\underline{012-9333-7}$

Tehrani, N. (2004). Workplace trauma: Concepts, assessment and interventions. Routledge.

World Health Organization (WHO). (2010). International Statistical Classification of Diseases and Related Health Problems 10th Revision (ICD-10) Version for 2010. World Health Organization. https://www.who.int/classifications/icd/ICD10Volume2 en 2010.pdf

Yaman-Karahan, B. (2016). Yassamdaki amas, duygusal iyi olus, kişisel ölüm korkusu ve duyarl sevginin ontolojik iyi oluş üzerindeki etkisi [The impact of purpose in life, emotional well-being, personal fear of death, and sensitive love on ontological well-being].[Unpublished thesis paper]. İstanbul Arel Üniversitesi.

Zika, S., \& Chamberlain, K. (1992). On the relation between meaning in life and psychological well-being. British Journal of Psychology, 83(1), 133-145. https://psycnet.apa.org/doi/10.1111/i.2044-8295.1992.tb02429.x 